\title{
事例研究
}

\section{自閉症児における既得の表現とは異なる 教示要求表現の形成と产の機能的差異}

\author{
佐 竹 真 次**小林 重 雄**
}

\begin{abstract}
すでに「これなあに？」という言語表現を獲得している1名の自閉症児を対象として、新 たに「教えてください」という言語表現を学校生活の日常的な場面でマンド・モデル法を用 いて訓練した。標的行動が形成され、他の日常生活の場面にも有効な般化が成立した。行動 の維持も長期にわたって確認された。また、「教えてください」の行動と「これなあに？」の 行動はそれぞれ訓練された状況と類似の状況においてのみ般化が成立し、その境界を越えて の般化は成立しにくかった。「教えてください」の行動は「問題解決のための手順に関する教 示を要求する機能」として生起し、一方、「これなあに?」の行動は「目前の対象物の名称等 に関する教示を要求する機能」として生起していることから、両者の機能的な差異が明らか に示された。
\end{abstract}

キー・ワード：自閉症児 教示要求表現 機能的差異 般化 維持

\section{I . はじめに}

自閉症児のコミュニケーション能力には語用論的な 障害があり、伝達機能の中でも相互作用的な叙述・報 告や教示要求などの機能の形成が著しく遅れることが 指摘されている (Tager-Flusberg, 1981 $\left.{ }^{8}\right)$ 。しかし、 これらの機能は自閉症児の日常生活や将来の社会生活 における社会的行動のためにも重要とされている (Garfin and Lord, 1986')。

その中でも、援助や教示を要求する表現は特に重要 なものの一つとされている。そのような言語表現は教 示要求表現、情報要求表現、応答誘発表現などと呼ば れ、それらの形成についてはさまざまな研究が試みら れ、その般化や維持に関しても一応の成果が示されて きた。例えば、山本 $\left(1987^{9}\right)$ は 3 名の自閉症児に、未 知刺激について「わからない。教えてください」とい う言語表現を形成し、既知刺激に関する正応答反応の みを分化強化することによって「わからない。教えて ください」という言語反応を未知刺激に対してのみ表 出させることに成功している。さらに、これは、場面 間の般化も類似刺激に対する般化もみられたが、経験

\footnotetext{
*東京学芸大学附属養護学校
}

**筑波大学心身障害学系
したことのない物品操作については般化がほとんどみ られなかったことを報告している。一方、佐竹・小林 $\left(1989^{6)}\right)$ 、藤原・佐野 $\left(1989^{11}\right)$ は、未知刺激に対して 情報要求表現ないしは応答誘発表現、すなわち指さし を伴う「なあに?」という言語反応を自閉症児に形成 し、般化のエピソードも示している。また、主に末知 刺激に対してのみ、この反応が表出されたことを報告 した。

しかし、これらの研究では、「なあに？」という言語 表現と「わからない。教えてください」という言語表 現とを単独に取り扱い、それらの言語表現の環境との 相互作用に基づく機能の違いを論究するまでには至ら なかった。また、物品操作の手順を知ることが必要な 状況への般化の問題も十分に検討されていない。さら に、これらの言語表現は臨床実験的な条件のもとで訓 練されたものであるが、こういった実用的言語スキル の訓練に際しては、より自然な日常生活場面における 訓練の検討が必要であると指摘されてきている。

そこで、本研究では、すでに「これなあに？」とい う言語表現を獲得している自閉症児に対して、新たに 「教えてください」という言語表現を学校生活の日常 的な場面で訓練し、その形成と般化、維持、および両 者の機能的な差異について検討する。 


\section{II. 方 法}

\section{1. 対象児}

精神遅滞を伴う自閉症児 $\mathrm{HS}_{\text {。 }}$ 自閉症の判定は、 DSM III-R の診断基準によった。養護学校中学部 1 年、CA $12 ： 7 、$ 田中ビネーによると MA $4: 9 、$ IQ 37 。 注意の被転導性が高く、集団における全体指示に従う ことには困難がみられる。個別指示に従えることは多 くなってきている。

1〜2 語文での発話が可能であるが、独り言やおうむ 返しが多い。大人からの問いかけがあると何らかの関 係のある応答や無関係な応答を表出する。しかし、伝 言や報告、質問等のコミュニケーションのために自発 的にことばを使うことは難しい。問題解決を迫られる 状況に置かれ、解決手段が見つからない場合や教師に 問い詰められたりすると、両耳を両手で強く押さえて 唸ったり、自分の手首を軽く啮んだり、教師を威嚇す るような素振りをしたり、といった軽いパニック状態 がみられる。

本実験以前の指導の結果、簡単な要求表現や「これ なあに?」という質問表現は形成されている。平仮名 と片仮名の読み書きはほほ正確にできる。日常生活に 密着した数十種類の漢字を読むことができる。しかし、 自分の名前以外の漢字を自発的に書くことはほとんど ない。

\section{2. 手続き}

学級の係の一つとして、HS を教室の背面黒板の日 課表にその日の学習予定を毎朝チョークで記入する係 にした。朝、生徒たちが登校すると、担任が「係の仕 事をお願いします」と言う。HSは椅子を持ってきてそ れに乗り、背面黒板の日課表に向かう。「マラソン」

「きゅうしょく」等の毎日の決まった活動名について は教えられなくても記入できるが、養護学校の指導計 画は非常に柔軟であるために、科目や下校時間等が週 時表どおりに定まらないことも多く、そのような変更 しやすい科目や下校時間等については教師に質問しな いとわからない。このような場合に HS が教師に向 かって「教えてください」と自発的に言うことを標的 行動とした。標的行動が表出されたら教師はすぐに笑 顔で「はい」と言って承認し、書くべき科目名等を教 える。

HS が困惑してそれを言えないでいる場合にはマン ド・モデル法 (Rogers-Warren and Warren, 19805) を適用する。すなわち、5〜10 秒間待ったうえでなん て言うの?」と言って反応を促す。それでも標的行動 を表出しない場合には「教えてください」というモデ
ルを示す。HS が適切に反応または模倣したら、標的行 動表出の場合と同様に、教師はすぐに笑顔で「はい」 と言って承認し、書くべき事柄を教える。教えた事柄 を HS が平仮名か片仮名で正しく書けたら、教師は「は い、ありがとう」と言って賞賛する。文字等の書き間 違いがみられた場合には、教師はそれを指さしや言語 指示で指摘して修正させる。

記録は、各機会の日時、場所、HS が従事していた活 動、聞き手、HS の反応の型、反応のタイミング、プロ ンプトの有無等に関して、反応を観察した度毎に筆記 によって行った。正反応すなわち標的行動であったか どうかの判断は、毎日の空き時間に記録を参照しなが ら同嘹との討論と合意のもとになされた。

\section{III. 結 果}

Fig. 1 に「教えてください」の正反応率の変化を示し た。このデータは、'90 年 9 月 5 日から 11 月 5 日まで (第 1 期) と、1 学期間のブランク（別の係になってい た）をおいて' 91 年 4 月 20 日から 7 月 15 日まで（第 2 期)、さらに 1 年間のブランクをおいで'92 年 9 月 2 日 から 9 月 7 日まで（第 3 期）の訓練期間におけるもの である。日課表を記入する際、標的行動が表出される 機会は、日によって1〜5回あった。記録できた日数は 62 日であった。1〜数日分をまとめて1ブロックとし たため、各ブロックあたりの機会数は一定ではないが、 4〜7 回の範囲におさまるようにした。正反応率を\%で 表示した。ブロック数は 43 となった。

当初、正反応率は $0 \%$ であった。日課を書き始めてわ からない部分にさしかかると、HS はチョークを持っ たまま黒板の前にしばらく立っており、そのうちに他 の場所に移動してしまっていた。教師が約 $2 \mathrm{~m}$ 以内に いると、無言で教師の手にチョークを握らせ、腕を持 ち、書かせようとした。その後、第 10 ブロックで正反 応率は $100 \%$ となった。

第 8、9 ブロックで「これなあに？」という反応が数 回みられた。母親によると、これは HSに 3 歳位から 絵の命名練習をさせているうちに、大人の「これなあ に? 」という問いかけを模倣するようになり、2 年生位 で自発するようになった反応である。この反応の出現 のため、その後の学習効率がよくなったという。

第 12 ブロック以降、教師が $5 \sim 6 \mathrm{~m}$ 離れていても標 的反応を表出するようになった。

その後 1 学期間のブランクをおき、再び同じ係に戻 して第 2 期訓練を行ったところ、第 $17 、 18$ ブロックで は正反応率が著しく低下してしまった。しかし、訓練 


\section{自閉症児における既得の表現とは異なる教示要求表現の形成とその機能的差異}

を続けると間もなく（第 19 ブロックで）正反応率が $100 \%$ とって、それ以降も維持された。さらにその後 1 年間のブランクをおき、また同じ係に戻したところ (第 3 期)、第 40 ブロックでも正反応率は低下するこ となく $100 \%$ が維持された。

対人般化と場面般化に関する情報は 44 例得られた。 これらの情報は、教室の授業時間や休み時間に偶然確 認できた般化行動を担任である $\mathrm{S}$ 先生が記録したも の、および母親が折に触れて連絡帳を通して報告して くれたものである。

Fig. 2 に、得られた 44 例の般化行動を示した。 $\mathrm{S}$ 先 生に対する「教えてください」は、訓練第 1 期に 1 例、 第 2 期には 2 例、第 2 期終了後には 22 例みられた。こ れなあに?」は第 2 期終了後に 11 例みられた。「これ なあに？教えてください」は第 2 期終了後に 2 例みら れた。

$\mathrm{T}$ 先生と $\mathrm{M}$ 先生に対する「教えてください」は第 2
期終了後にそれぞれ 2 例と 1 例みられた。母親に対す る「教えてください」は、第 1 期終了直後に 1 例、第 3 期終了後に 1 例みられ、「これなあに？」は第 2 期終 了後に 3 例みられた。

Table 1 に、般化行動の生起場面・目的・機能、およ びそれらに対する各反応型の出現回数を示した。観察 できた場面・目的は大まかに分けて 9 種類見られた。 これらのうち、「作業・制作の手順・方法について」「日 常生活に関する行動の手順・方法について」「スケ ジュール手帳・タイムカードの記入方法について」「日 直で日付書きのとき、今日の日にちについて」「機械等 の操作手順について」「指示・質問・設問の不理解を解 決する方法について」の 6 種類の場面・目的において 生起した行動の機能を、問題解決のための手順に関す る教示を要求する機能であるとみなし、手順教示要求 機能」として分類した。一方、「文字、文の読み方につ いて」「大人が作っている物、使っている物について」

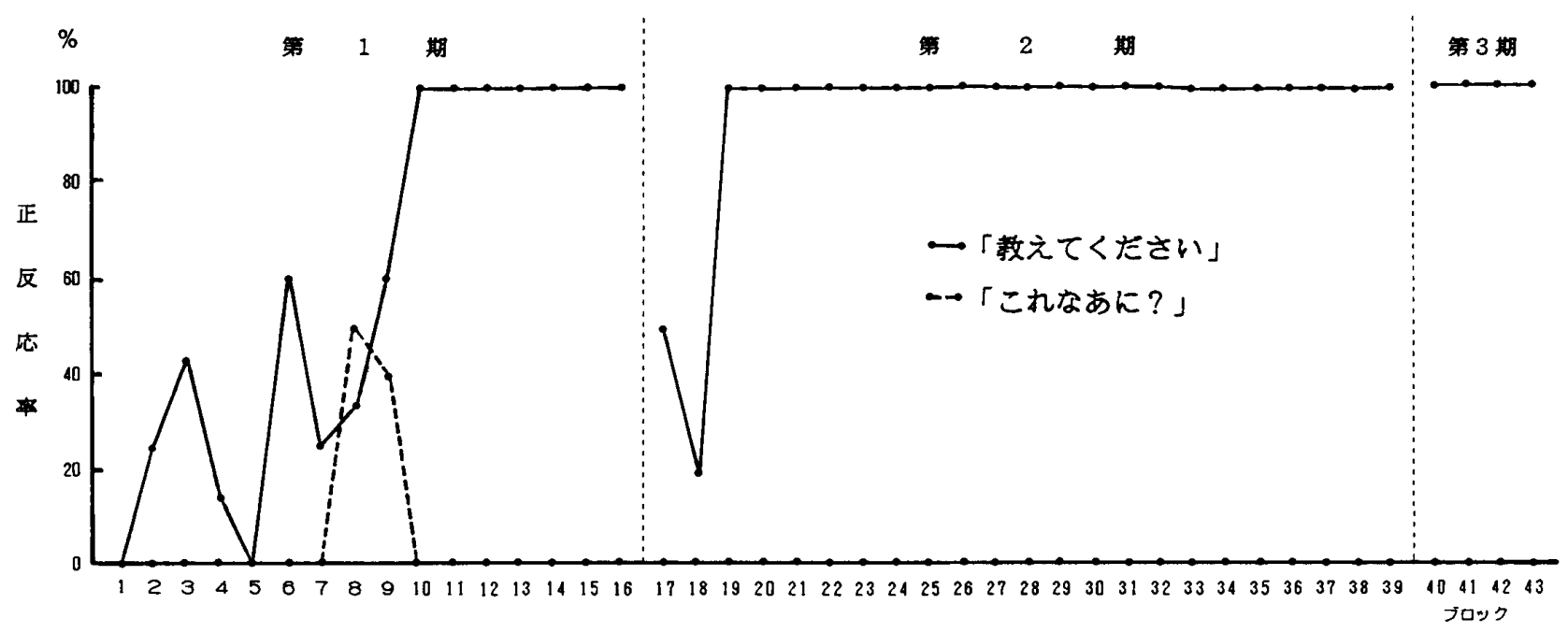

Fig. 1 HSの「教えてください」の正反応率

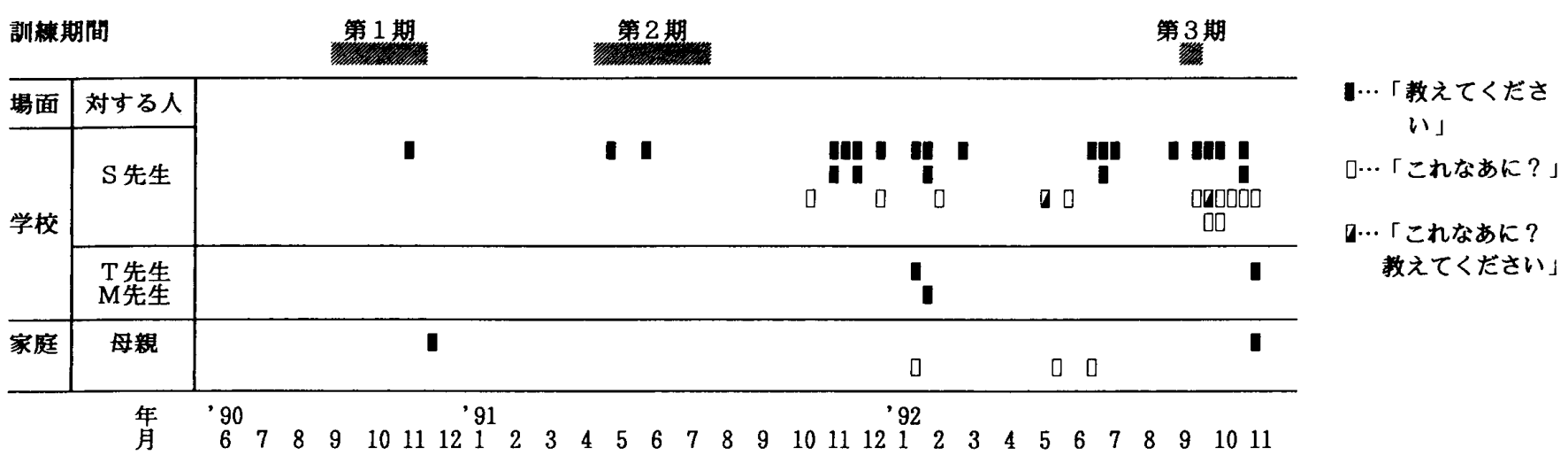

Fig. 2 HSの教示要求表現の般化状況 
Table 1 般化行動の生起場面 (目的) と機能、およびそれらに対する各反応型の出現回数

\begin{tabular}{|c|c|c|c|c|c|c|}
\hline \multirow[b]{2}{*}{ 場 } & \multirow[b]{2}{*}{ 面 } & \multirow[b]{2}{*}{ - 目 } & \multirow[b]{2}{*}{ 的 } & \multicolumn{2}{|c|}{ 反 } & 型 \\
\hline & & & & 「教えてください」 & 「これなあに？」 & $\begin{array}{l}\ulcorner こ れ な あ に ？ \\
\text { 教えてください」 }\end{array}$ \\
\hline \multicolumn{7}{|c|}{ 手順教示要求機能 (問題解決のための手順に関する教示を要求する機能) } \\
\hline \multicolumn{4}{|c|}{ 作業・制作の手順・方法について } & 9 & & \\
\hline \multicolumn{4}{|c|}{ スケジュール手帳・タイムカードの記入方法について } & 8 & & \\
\hline \multicolumn{4}{|c|}{ 機械等の操作手順について } & 3 & & \\
\hline \multicolumn{4}{|c|}{ 指示・質問・設問の不理解を解決する方法について } & 3 & & \\
\hline \multicolumn{4}{|c|}{ 日常生活に関する行動の手順・方法について } & 2 & & \\
\hline \multicolumn{4}{|c|}{ 日直で日付書きのとき,今日の日にちについて } & 2 & & \\
\hline \multicolumn{7}{|c|}{ 名称教示要求機能 (目前の対象物の名称等に関する教示を要求する機能) } \\
\hline \multicolumn{4}{|c|}{ 文字, 文の読み方について } & 1 & 8 & 2 \\
\hline \multicolumn{4}{|c|}{ 新奇な物・絵について } & & 4 & \\
\hline \multicolumn{4}{|c|}{ 大人が作っている物や使っている物について } & & 2 & \\
\hline
\end{tabular}

$「$ 新奇な物・絵について」の 3 種類の場面・目的にお いて生起した行動の機能を、目前の対象物（漢字をも 含む）の名称等に関する教示を要求する機能であると みなし、「名称教示要求機能」として分類した。

「作業・制作の手順・方法について」生起した教示 要求行動の例には、手芸の時間に HS が刺繣をしてい る途中で針から糸がはずれてしまい、教師に近づいて きて「教えてください」と言ったことなどが挙げられ る。「新奇な物・絵について」生起した教示要求行動の 例には、修学旅行のときに京都で食べる予定の食事の 写真を初めて見せられた際、それを指さして「これな あに？」と言ったことなどが挙げられる。

「手順教示要求機能」として生起した反応は、「教え てください」が 27 回で、「これなあに？」は 0 回であっ た。「名称教示要求機能」として生起した反応は、「こ れなあに?」が 14 回で、「教えてください」が 1 回、 「これなあに? 教えてください」が 2 回であった。

\section{IV. 考 察}

\section{1. 強化・般化・維持について}

学校生活におけるコミュニケーション・スキルの訓 練では、生活のルーチンがある程度確立していれば、 その中に標的行動の機会を組み入れることによって、 比較的容易に標的行動を形成することが可能である (佐竹・山口・鶴田, 19897)。そのルーチンを達成する こと自体が強化因ともなりうるので、行動形成の初期 であっても、社会的な正の強化因を適宜に随伴させる 程度で十分であることも多い。
養護学校では対象児に複数の指導者がかかわり、さ らにクラスメイトも教示要求行動の受け手となること があるために対人般化が促進されやすい。また、家庭 との毎日の連絡のやりとりによって、必要な標的行動 やその習得状況について家族と協議・検討することも 容易であり、家庭への般化も実現しやすい。

長期間の非訓練事態の後に突然訓練場面が再導入さ れても、正反応は高率で維持されるようになった。こ れは、般化行動がさまざまな場面で日常的に出現する ようになったことにより、相対的に訓練場面の特殊性 が低くなったためであると考えられる。

\section{2. 二種類の行動の機能的差異について}

「教えてください」行動の訓練場面において、「これ なあに?」という行動が第 $8 、 9$ ブロックで数回みられ、 その後出現しなくなった。その行動に対しては消去操 作や修正は行わなかったが、モデル提示の際には「教 えてください」という反応型のみを提示した。その結 果、HSは「教えてください」行動を自発的に選択する ようになったものと考えられる。

「これなあに?」という行動は、当初、絵の命名反 応を促すという状況で形成された。一方、教えてくだ さい」という行動は、日課表の黒板に必要事項をすべ て記入するという一連の仕事（問題）を解決するとい う状況で形成された。

結果に見られるように、これらはそれぞれ訓練され た状況と類似の状況に扔いて般化が成立し、その境界 を越えての般化は成立しにくかった。そして、それら は各々目前の対象物の名称等に関する教示を要求する 
機能と問題解決のための手順に関する教示を要求する 機能に関連するようになったと考えられる。

なお、名称教示要求機能として「教えてください」 の行動が 1 回出現しているが、これはこの機能に対す る反応選択の混乱によるものと考えられる。また、同 じ機能として「これなあに？教えてください」の行動 が 2 回出現しているが、この際の「教えてください」 は、「これなあに？」に対する相手からの反応をさらに 催促するための役割を持つもので、具体的な「手順」 の教示要求とは言えないまでも、広い意味では問題解 決のための教示要求の機能と考えることもできよう。 ともあれ、「教えてください」行動に関する機能の境界 線には明確でない部分もうかがわれるが、ほとんどの 「教えてください」行動は問題解決のための手順教示 要求機能として生起している。

角張 $\left(1985^{4)}\right)$ 、山本 $\left(1987^{9)}\right)$ は名称等の教示要求の 機能として「教えて（ください）」という行動を自閉症 児に形成し、般化のエピソードや般化テストの結果も あげている。しかし、角張 $\left(1985^{4)}\right)$ には名称教示要求 以外の機能としてこの「教えて（ください）」という行 動が般化したという例は記されていない。また、山本 $\left(1987^{9)}\right)$ では物品操作についての教示の要求という 機能への般化はほとんどみられなかった。物品操作に ついての教示要求とは、本論でいう手順教示要求と同 等の機能であると考えられる。

さらに、藤原・佐野 $\left(1989^{1)}\right)$ 、佐竹・小林 $\left(1989^{6)}\right)$ は名称等の教示要求の機能で「なあに？」という行動 を形成し、名称教示要求の範囲内での般化のエピソー ドを紹介しているが、名称教示要求以外の機能として この「なあに?」という行動が般化したという例は報 告していない。

これらのことから、これら 2 種類の教示要求機能は 異なったものであると考えられる。したがって、伝達 機能の観点から見れば、トポグラフィーはともあれ、 これらは独立した機能として訓練される必要のあるこ とが示唆されよう。

\section{3. 名称等に関する教示要求表現の問題点について}

山本 $\left(1987^{9)}\right)$ は、既知刺激に関する正応答反応のみ を分化強化することによって、教示要求行動を未知刺 激に対してのみ表出させることに成功している。一方、 角張 $\left(1985^{4}\right)$ は、未知刺激についての「教えて」行動 に対して食物強化因を提示し、既知刺激についての正 応答反応に対して社会性強化因を提示することによっ て、既知であるか未知であるかについて適切に選択的 に反応するようになったという。
本論の HS の学級では、例えば「美術」の授業は月 に 2 回、「合宿」は年に 2 回しかなく、これらの教科名・ 活動名の読み方の学習は定着しにくい状況に置かれて いた。そのため、既知であって、自発的に正しく読ん だ経験のあるこれらの漢字に関しても、「これなあ に?」行動を表出することもあった。しかしながら、 週 2 回行う「国語」や毎日もたれる「給食」等の学習 機会の多い教科名・活動名の漢字については、敢えて 「これなあに?」行動を表出することはなく、分化強 化などの特別な操作を加えなくとも、実用上差し支え ない程度に適切に反応を選択していたと言うことがで きる。

\section{4. 手順に関する教示要求表現の問題点について}

問題解決を迫られる状況に置かれても、HS は「教え てください」という教示要求行動を表出することで教 示を与えられるために、パニック状態に陥ることもほ とんどみられなくなった。そのような HS の行動変容 を母親をはじめとする家族は非常に歓迎した。

HS の場合、「教えてください」行動は一日数回しか 聞かれない行動であり、それほどわずらわしいとは思 われなかった。しかし、筆者の同僚の中には、その行 動が広範囲に般化し出現頻度も高くなれば、仮に問題 解決の手順に関する知識を持っていても、自発的に問 題解決のための作業を始めるよりも先に安易に教示を 要求してしまう場合が生じてくるのではないか、と指 摘する者もあった。

このような問題が起きた場合には、対象児の記憶に 蓄積されている作業手順等に関する知識の状況といっ た内的刺激をも弁別刺激に含めた上で教示要求行動を 表出するように分化強化していくことが重要であろ う。また、コミュニケーションの手段とはいえ、過剩 な質問癖 (Hurtig, Ensrud, and Tomblin, 1982 ${ }^{3)}$ ) 獲得しやすいタイプの自閉症児の場合は、教示要求表 現の訓練の期間の長さや、その訓練そのものの導入の 適否を事前に慎重に検討する必要があると思われる。

\section{文 献}

1）藤原義博·佐野とも子 (1989) 自閉症児の応答誘発 表現の形成. 日本特殊教育学会第 27 回大会発 表論文集, 432-435.

2) Garfin, D. G. and Lord, C. (1986) 自閉症におけ る社会性の問題としてのコミュニケーション. In Schopler, E. and Mesibov, G. B. (Eds.), Social Behavior in Autism. Plenum Press. 久野能弘 宮下照子 (監訳) (1990)：自閉症児の社会的行動 
I. 岩崎学術出版社, 165-187.

3) Hurtig, R., Ensrud, S., and Tomblin, J. B. (1982)

The communicative function of question in autistic children. Journal of Autism and Developmental Disorders, 12 (1), 57-69.

4) 角張憲正 (1985) 自閉児の言語開発一サバイバル スキルとしての言語指導一. 学習研究社, 84 $-89$.

5) Rogers-Warren, A. and Warren, S. F. (1980) Mand for verbalization: Facilitating the display of newly trained language in children. Behavior Modification, 4, 361-382.

6) 佐竹真次・小林重雄 (1989) 自閉症児における情報
要求表現の形成. 日本特殊教育学会第 27 回大 会発表論文集, 476-477.

7) 佐竹真次 - 山口知子・鶴田菜穂子 (1989) 重度精神 遅帯児における学校生活の文脈を利用した要求 動作の形成. 精薄教育 (日本精薄教育研究会, 東 洋大学文学部), 352, 5-8.

8) Tager-Flusberg, H. (1981) On the nature of linguistic functioning in early infantile autism. Journal of Autism and Developmental Disorders, 11 (1), 45-56.

9) 山本淳一 (1987) 自閉児における教示要求表現の 形成. 教育心理学研究, 35, 97-106.

-1993.8.3. 受稿, 1993.12.11. 受理一

Jap. J. Spec. Educ., 32 (1), 27-32, 1994.

\title{
Learning a New Expression for Requesting Instructions : A Functional Difference Between the New Expression and a Previously Learned One in a Child with Autism
}

\author{
Shinji SATAKE* and Shigeo KobAYASHI** \\ * Special School for the Mentally Retarded, Tokyo Gakugei University \\ (Higashi Kurume-Shi, 203) \\ **Institute of Special Education, University of Tsukuba \\ (Tsukuba-Shi, 305)
}

A new verbal expression, "Please explain", was taught to a child with autism who had already acquired another verbal expression, "What's this?", in the setting of his daily school activities, employing the Mand-Model method. The target behavior was learned, and it was generalized effectively into other daily living situations. Also its maintenance for a long period was observed.

Moreover, the behaviors "Please explain" and "What's this?" were generalized only to situations that were similar to the condition in which each of the behaviors had been taught. The behavior "Please explain" occurred when some instructions were required relating to the procedure necessary to resolve a current problem. The behavior "What's this?" occurred when some instructions relating to the label of an object in front of the child were required. This suggested that a functional difference had been established between these two expressions in this autistic child.

Key Words : requesting instructions, functional difference, generalization, maintenance, child with autism 